\title{
Cultural and Morphologically Variability in Different Colletotrichum lagenarium Isolates of Bottle Gourd in Haryana
}

\author{
Ankit Kumar, Narender Singh*, Kushal Raj, R.S. Chauhan and Manoj Kumar
}

Department of Plant Pathology, CCS, Haryana Agricultural University, Hisar-125004, India

*Corresponding author

\section{A B S T R A C T}

Bottle gourd (Lagenaria siceraria) is one of the important cucurbitaceous vegetable crop being grown both during warm and rainy season in northern parts of India. It has wide

Keywords

Bottle gourd,

Variability,

Conidia,

Sporulation and

isolates

Article Info

Accepted:

04 May 2019

Available Online:

10 June 2019 genetic diversity and is grown throughout the tropics and subtropics of the world. Bottle gourd is prone to various fungal bacterial and viral diseases. Among various fungal diseases Anthracnose, Downy mildew and Cercospora leaf spot are widely prevalent in different bottle gourd growing areas. Anthracnose caused by Colletotrichum lagenarium (Pass.) Ellis. and Halsted is of major economic importance. Keeping in view the importance of this disease in this region, the present investigation was carried out under laboratory condition in the department of Plant Pathology during 2016 at CCS, HAU, Hisar. In the variability studies, potato dextrose agar medium was found best medium for growth of Colletotrichum lagenarium. The fungus grew well at $6.5 \mathrm{pH}$ and $30^{\circ} \mathrm{C}$ temperature, whereas, minimum growth of fungus was observed on oat meal agar medium at $7.5 \mathrm{pH}$ and $35^{\circ} \mathrm{C}$ temperature. Among various isolates Karnal (CL2) and Kaithal (CL3) isolates were found fast growing. Least growth was observed in Yamuna nagar (CL5) isolate. Maximum conidia size and sporulation was recorded in Karnal (CL2) isolate grown on potato dextrose agar media at $35^{\circ} \mathrm{C}$ temperature and $6.5 \mathrm{pH}$.

\section{Introduction}

Bottle gourd (Lagenaria siceraria) is one of the important cucurbitaceous vegetable crop grown extensively throughout the world. The origin of bottle gourd is assumed from Africa and domestication occurred in tropical low lands of south Central America. In India bottle gourd is cultivated in an area of 103.23 thousand ha with productivity of 17.61 ton/ha (Anonymous, 2016). In Haryana bottle gourd is cultivated during summer and rainy season.
Bottle gourd is prone to various fungal bacterial and viral diseases. Among various fungal diseases Anthracnose, Downy mildew and Cercospora leaf spot are widely prevalent in different bottle gourd growing areas. Anthracnose caused by Colletotrichum lagenarium (Pass.) Ellis. and Halsted is of major economic importance. Anthracnose disease was first reported by Gardner (1918) from USA and by Mundkur (1937) from India. Several species of plant pathogenic fungi under the genus Colletotrichum cause anthracnose in bottle gourd, other vegetables 
and fruits. Anthracnose of bottle gourd regularly occurs in different bottle gourd growing area during both the seasons. The pathogen is seed borne in nature but initiation as well as spread of disease largely depends upon the environmental factors. This disease is widespread under both greenhouse and field cultivation resulting in poor fruit quality and yield. Direct infection on the fruit also results in loss of market value.

The symptoms appears as brownish specks, which grows into angular and roughly circular spots on the leaves, whereas on young fruits numerous water soaked, depressed, oval or circular spots are observed. Colletotrichum lagenarium also cause premature plant death by reducing the photosynthetic surface area to the extent of $29-42 \%$, resulting in yield losses of 6-48\%. The disease is reported to occur in epiphytotic form in India (Madan and Grover, 1977) and Japan (Kobayshi et al., 1998).

Traditionally, Colletotrichum species have been identified and delimited on morphological characters. Several features have been utilized by taxonomists including size and shape of conidia and appressoria, presence or absence of setae, sclerotia, acervuli and teleomorph state and cultural characters such as colony, growth rate and texture (Photita et. al., 2005; Than et. al., 2008a; Thaung, 2008). These criteria alone are not always adequate for reliable differentiation among Colletotrichum species due to variation in morphology and phenotype among species under environmental influence. Some taxa have uncertain or extensive host relationship and pathological variations and are often morphologically variable in culture (Freeman et. al., 2000; Latunde-Dada, 2001; Du et. al., 2005; Thaung, 2008). By keeping its importance of this disease in this region, the present study has been taken up with the objectives to study cultural and morphologically variability in
Colletotrichum lagenarium causing anthracnose of bottle gourd.

\section{Materials and Methods}

The present studies on cultural and morphologically variability of bottle gourd anthracnose caused by Colletotrichum lagenarium (Pass.) Ellis and Halsted was carried out during 2016 in the laboratory Department of Plant Pathology, College of Agriculture, CCS Haryana Agricultural University, Hisar. The details of the material used and methodology adopted during the course of this investigation are given below.

\section{Collection of samples, isolation, purification and maintenance of Colletotrichum lagenarium}

The fruits and leaves of bottle gourd having characteristic symptoms of anthracnose were collected from different locations of Haryana. These samples were subjected to isolation and purification of the pathogen. Infected portions of diseased leaves were cut into small pieces. The cut pieces of infected portion were surface sterilized with 0.1 per cent mercuric chloride solution for 30 seconds followed by 3-4 washings in sterile distilled water. The cut pieces were then aseptically transferred to Petri dishes containing potato dextrose agar (PDA) medium and inoculated at $28 \pm 1{ }^{\circ} \mathrm{C}$ for 8 days. The single spore isolation was done to purify the culture after 8 days of inoculation. The test fungus was identified as Colletotrichum lagenarium based on the cultural and morphological characteristics (Madan and Grover, 1977). The stock culture of fungus was multiplied on PDA slants at $28 \pm 1^{\circ} \mathrm{C}$ and maintained by subculturing and stored at $5 \pm 1^{\circ} \mathrm{C}$. This stock culture was used for future work. The different isolates collected from different locations of Haryana are summarized in Table 1. 


\section{Variability studies}

\section{Morphological variations}

The Petri plates poured with Potato dextrose agar and Oat meal agar medium with different $\mathrm{pH}$ i.e. $6.5,7.0$ and 7.5 were inoculated with seven days old $5 \mathrm{~mm}$ culture disc of different isolates of Colletotrichum lagenarium and incubated for ten days at 25,30 and $35^{\circ} \mathrm{C}$ by maintain four replications in completely randomized block design. The morphological characters viz., colony colour, size of conidia and shape of conidia were examined.

\section{Cultural variations}

\section{Growth of $C$. lagenarium on different} media

The morphological and cultural characteristics were examined on two medium i.e. Potato dextrose agar and Oat meal agar media sterilized at $15 \mathrm{lb}$ pressure per square inch for 20 minutes with $\mathrm{pH}$ of media was adjusted at $6.5,7.0$ and 7.5 by adding $0.1 \mathrm{~N}$ $\mathrm{NaOH}$ or $0.1 \mathrm{~N} \mathrm{HCL}$.

The composition of Potato Dextrose Agar and Oat meal Agar are given below:

\section{Potato dextrose agar medium}

$\begin{array}{lc}\text { Peeled potato extract } & 200 \mathrm{~g} \\ \text { Dextrose } & 20.0 \mathrm{~g} \\ \text { Agar agar } & 20.0 \mathrm{~g} \\ \text { Distilled water } & 1000 \mathrm{ml}\end{array}$

\section{Oat meal agar medium}

$\begin{array}{ll}\text { Oat-meal } & 40.0 \mathrm{~g} \\ \text { Agar agar } & 20.0 \mathrm{~g} \\ \text { Distilled water } & 1000 \mathrm{ml}\end{array}$

Twenty five $\mathrm{ml}$ of medium was poured aseptically in each Petri dish and allowed to solidify. The Petri plates were inoculated with $5 \mathrm{~mm}$ mycelial disc obtained from 8-10 days old culture of different isolates. The inoculated Petri dishes were incubated at 25, 30 and $35^{\circ} \mathrm{C}$ temperature in BOD incubators by maintaining four replications. The radial growth in each case was determined by taking average of the colony diameter in two directions at regular interval of $48 \mathrm{~h}$ upto ten days of inoculation.

\section{Sporulation of isolates on different media}

To study the extent of sporulation, four mycelial bits ( $5 \mathrm{~mm}$ each) were taken with the help of a cork borer from the periphery of Petri plates cultures and mashed in $10 \mathrm{ml}$ of distilled water and shaked thoroughly. Drops were taken from the suspension and the number of conidia was counted with the help of heamocytometer and sporulation was expressed as number of conidia $\mathrm{ml}^{-1}$ of suspension.

\section{Results and Discussion}

Cultural and morphological variability in different Colletotrichum lagenarium isolates

C. lagenarium the incitant of bottlegourd anthracnose isolates of five locations were evaluated on PDA and OMA (pH 6.5, 7.0 and 7.5) at different temperature viz., $25^{\circ} \mathrm{C}, 30^{\circ} \mathrm{C}$ and $35^{\circ} \mathrm{C}$.

Mycelial growth of $C$. lagenarium isolate (s) on Potato dextrose agar (PDA) and Oat meal agar (OMA) at different temperature (pH 6.5)

C. lagenarium the incitant of bottle gourd anthracnose isolates of five locations were evaluated on PDA and OMA ( $\mathrm{pH}$ 6.5) at different temperature viz., $25^{\circ} \mathrm{C}, 30^{\circ} \mathrm{C}$ and $35^{\circ} \mathrm{C}$. The observations are computed in Table 2. It is evident from the results that the 
mycelial growth of each isolate was maximum at $30^{\circ} \mathrm{C}$ irrespective of the medium used. Amongst different isolates of $C$. lagenarium, the growth of designated isolate as CL2 of Karnal location was maximum irrespective of the medium used or incubated at $25^{\circ} \mathrm{C}, 30^{\circ} \mathrm{C}$ and $35^{\circ} \mathrm{C}$. The growth of Karnal isolate was better on PDA in comparison to OMA medium.

Mycelial growth of $C$. lagenarium isolate(s) on Potato dextrose agar (PDA) and Oat meal agar (OMA) at different temperature (pH 7.0)

C. lagenarium the incitant of bottle gourd anthracnose isolates of five locations were evaluated on PDA and OMA (pH 7.0) at different temperature viz., $25^{\circ} \mathrm{C}, 30^{\circ} \mathrm{C}$ and $35^{\circ} \mathrm{C}$ (Table 3). The mycelial growth of each isolate was maximum at $30^{\circ} \mathrm{C}$ irrespective of the medium used (Table 4). However mycelial growth of the each isolate comparatively slow at $\mathrm{pH}$ 7.0. Amongst the different isolates of $C$. lagenarium, the designated isolate as CL2 of Karnal location growth was maximum irrespective of the medium used or incubated at $25^{\circ} \mathrm{C}, 30^{\circ} \mathrm{C}$ and $35^{\circ} \mathrm{C}$. The growth of Karnal isolate (CL2) was superior on PDA in comparison to OMA medium.

Mycelial growth of $C$. lagenarium isolate (s) on Potato dextrose agar (PDA) and Oat meal agar (OMA) at different temperature (pH 7.5)

C. lagenarium the incitant of bottle gourd anthracnose isolates of five locations were evaluated on PDA and OMA $(\mathrm{pH} \mathrm{7.5)}$ at different temperature viz., $25^{\circ} \mathrm{C}, 30^{\circ} \mathrm{C}$ and $35^{\circ} \mathrm{C}$. It is evident from the Table 4 that the mycelial growth of each isolate was maximum at $30^{\circ} \mathrm{C}$ irrespective of the medium used. However, mycelial growth of the each isolate was slow at $\mathrm{pH} 7.5$ in comparison to
$\mathrm{pH} 6.5$ and $\mathrm{pH}$ 7.0. Amongst different isolates of $C$. lagenarium, the growth of designated isolate as CL2 of Karnal location was maximum irrespective of the medium used or incubated at $25^{\circ} \mathrm{C}, 30^{\circ} \mathrm{C}$ and $35^{\circ} \mathrm{C}$. The growth of fast growing isolate of $C$. lagenarium (CL2) of Karnal location was superior on PDA medium (pH 6.5 at $30^{\circ} \mathrm{C}$ ).

The results of present are in positive agreement with the findings of Vanan (2001) reported that the optimum temperature for the growth of Colletotrichum capsici was $30^{\circ} \mathrm{C}$. Similarly, Photita et. al., (2005) and Deyol (2010) also reported $30^{\circ} \mathrm{C}$ as optimum temperature for the growth of $C$. capsici.

\section{Conidial size and colony colour of different isolates on different media}

The size and shape of $C$. lagenarium isolate's conidia were examined after 10 days of inoculation on PDA and OMA medium $(\mathrm{pH}$ $6.5)$ at $30^{\circ} \mathrm{C}$. The observations of conidial size and colony colour are presented in Table 5. The conidia size of Karnal isolate (CL2) was maximum on both the medium i.e. PDA (15$26 \times 4.4-5.9)$ and OMA $(15-26 \times 4.8-5.7)$ in comparison to other isolates. The conidial size of different isolates was in corroborative to that of the growth pattern of the isolates on different medium as well as $\mathrm{pH}$. The colony colour of the different isolates at frequent interval of the incubation remain variable from white to that of light brownish tinch. The colony colour of less sporulating isolate of Yamuna nagar location was light brownish. There was uniform conidia shape i.e ovoid type irrespective of each isolate grown on different medium. Davis et. al., (1992) reported variability in conidial size within isolates of C. gloeosporioides. Variation in conidial size, sporulation and growth pattern were observed among the isolates collected from different locations (Zakaria, 2000). In present investigation, all the isolates showed 
higher conidial production on PDA medium as compared to OMA medium. However, Lenne et. al., (1984) found that OMA was superior to PDA for comparing and distinguishing Colletotrichum in culture. From the review of literature it is evident that no such specific study has been carried out indicating the distinction of spore size within the isolates.

Sporulation pattern of $C$. lagenarium on different media ( $\mathrm{pH} \mathrm{6.5)}$ at temperature $30^{0} \mathrm{C}$

The sporulation pattern of each isolate was examined on different media at $30^{\circ} \mathrm{C}$ and the observations are computed in Table 6. It is evident from the results that the sporluation pattern was significantly superior on PDA medium in comparison to that of OMA medium. The sporluation of Karnal isolate (CL2) was maximum $\left(74.86 \times 10^{4}\right)$ on PDA medium in comparison to other isolates. Palarpawar (1987) also found variation in sporulation pattern of $C$. capsici and $C$. curcumae on different media i.e. $\mathrm{KNO}_{3}$ glucose medium, Potato dextrose agar medium, Dasgupta's standard medium and dextrose asparagines phosphate medium. In present investigation it was found that sporulation for all isolates was most abundant on PDA. Jeyalakshmi and Seetharaman (1999) also reported that maximum sporulation of $C$. capsici occurred on PDA followed by Czapek's dox agar and Richard's agar. Christopher et. al., (2013) also reported that different isolates of $C$. capsici showed profuse sporulation on PDA medium.

Table.1 Isolate collected from different locations of Haryana

\begin{tabular}{|r|c|c|c|}
\hline S. N. & Location & Host (variety/hybrid) & $\begin{array}{c}\text { Colletotrichum lagenarium } \\
\text { isolate }\end{array}$ \\
\hline $\mathbf{1}$ & Kurukshetra & Pusa Naveen & CL1 \\
\hline $\mathbf{2}$ & Karnal & Pusa Meghdoot & CL2 \\
\hline $\mathbf{3}$ & Kaithal & GH-3 & CL3 \\
\hline $\mathbf{4}$ & Ambala & PSPL & CL4 \\
\hline $\mathbf{5}$ & Yamuna nagar & Pusa Naveen & CL5 \\
\hline
\end{tabular}

Table.2 Mycelial growth of different isolates on different media and temperature at $\mathrm{pH} 6.5$

\begin{tabular}{|c|c|c|c|c|c|c|c|}
\hline \multirow{3}{*}{ Isolates } & \multirow{3}{*}{$\begin{array}{c}\text { Media } \rightarrow \\
\underset{\rightarrow}{\text { Temperature }}\end{array}$} & \multicolumn{6}{|c|}{ Mycelial growth (mm) } \\
\hline & & \multicolumn{3}{|c|}{ Potato dextrose agar } & \multicolumn{3}{|c|}{ Oat meal agar } \\
\hline & & $25^{\circ} \mathrm{C}$ & $3^{\circ} \mathrm{C}$ & $35^{\circ} \mathrm{C}$ & $25^{\circ} \mathrm{C}$ & $3^{\circ} \mathrm{C}$ & $35^{\circ} \mathrm{C}$ \\
\hline \multicolumn{2}{|c|}{ Colletotrichum lagenarium (CL1) } & 86.75 & 90.00 & 76.50 & 80.50 & 82.50 & 68.75 \\
\hline \multicolumn{2}{|c|}{ Colletotrichum lagenarium (CL2) } & 90.00 & 90.00 & 80.50 & 84.50 & 90.00 & 75.50 \\
\hline \multicolumn{2}{|c|}{ Colletotrichum lagenarium (CL3) } & 84.75 & 90.00 & 75.00 & 76.75 & 82.50 & 71.00 \\
\hline \multicolumn{2}{|c|}{ Colletotrichum lagenarium (CL4) } & 82.50 & 87.50 & 68.75 & 72.50 & 81.50 & 61.75 \\
\hline \multicolumn{2}{|c|}{ Colletotrichum lagenarium (CL5) } & 71.50 & 80.50 & 63.50 & 65.50 & 78.50 & 56.00 \\
\hline \multirow{2}{*}{\multicolumn{2}{|c|}{ C.D(p=0.05) }} & Media (M) & \multicolumn{2}{|c|}{$\begin{array}{l}\text { Temperature } \\
\text { (T) }\end{array}$} & $\begin{array}{l}\text { Isolates } \\
\text { (I) }\end{array}$ & \multicolumn{2}{|c|}{$\begin{array}{c}\text { Interaction } \\
\text { (M X T X I) }\end{array}$} \\
\hline & & 0.56 & \multicolumn{2}{|c|}{0.686} & 0.886 & \multicolumn{2}{|c|}{2.169} \\
\hline \multicolumn{2}{|l|}{ SE(m) } & 0.20 & \multicolumn{2}{|c|}{0.244} & 0.315 & \multicolumn{2}{|c|}{0.772} \\
\hline
\end{tabular}


Table.3 Mycelial growth of different isolates on different media and temperature at $\mathrm{pH} 7.0$

\begin{tabular}{|c|c|c|c|c|c|c|c|}
\hline \multirow[t]{3}{*}{ Isolates } & \multirow[t]{2}{*}{ Media $\rightarrow$} & \multicolumn{6}{|c|}{ Mycelial growth (mm) } \\
\hline & & \multicolumn{3}{|c|}{ Potato dextrose agar } & \multicolumn{3}{|c|}{ Oat meal agar } \\
\hline & Temperature $\rightarrow$ & $25^{\circ} \mathrm{C}$ & $30^{\circ} \mathrm{C}$ & $35^{\circ} \mathrm{C}$ & $25^{\circ} \mathrm{C}$ & $30^{\circ} \mathrm{C}$ & $35^{\circ} \mathrm{C}$ \\
\hline \multicolumn{2}{|c|}{ C. lagenarium (CL1) } & 82.50 & 84.50 & 71.50 & 74.50 & 78.25 & 66.50 \\
\hline \multicolumn{2}{|c|}{ C. lagenarium (CL2) } & 90.00 & 90.00 & 74.50 & 82.50 & 85.50 & 72.50 \\
\hline \multicolumn{2}{|c|}{ C. lagenarium (CL3) } & 81.00 & 90.00 & 69.25 & 71.50 & 75.50 & 63.50 \\
\hline \multicolumn{2}{|c|}{ C. lagenarium (CL4) } & 77.50 & 80.50 & 66.50 & 72.50 & 76.50 & 56.50 \\
\hline \multicolumn{2}{|c|}{ C. lagenarium (CL5) } & 65.50 & 73.50 & 60.50 & 60.50 & 73.50 & 53.50 \\
\hline \multirow{2}{*}{\multicolumn{2}{|c|}{ C.D $(p=0.05)$}} & Media (M) & \multicolumn{2}{|c|}{ Temperature $(\mathrm{T})$} & Isolates (I) & \multicolumn{2}{|c|}{ Interaction (MxTxI) } \\
\hline & & 0.415 & \multicolumn{2}{|c|}{0.508} & 0.655 & \multicolumn{2}{|c|}{1.605} \\
\hline \multicolumn{2}{|l|}{ SE(m) } & 0.148 & \multicolumn{2}{|c|}{0.181} & 0.233 & \multicolumn{2}{|c|}{0.571} \\
\hline
\end{tabular}

Table.4 Mycelial growth of different isolates on different media and temperature at $\mathrm{pH} 7.5$

\begin{tabular}{|c|c|c|c|c|c|c|c|}
\hline \multirow[t]{3}{*}{ Isolates } & \multirow{3}{*}{$\begin{array}{l}\text { Media } \rightarrow \\
\text { Temperatu } \\
\text { re }\end{array}$} & \multicolumn{6}{|c|}{ Mycelial growth (mm) } \\
\hline & & \multicolumn{3}{|c|}{ Potato dextrose agar } & \multicolumn{3}{|c|}{ Oat meal agar } \\
\hline & & $25^{\circ} \mathrm{C}$ & $30^{\circ} \mathrm{C}$ & $35^{\circ} \mathrm{C}$ & $25^{\circ} \mathrm{C}$ & $30^{\circ} \mathrm{C}$ & $35^{\circ} \mathrm{C}$ \\
\hline \multicolumn{2}{|c|}{ C. lagenarium (CL1) } & 76.50 & 79.75 & 66.00 & 68.50 & 73.25 & 61.50 \\
\hline \multicolumn{2}{|c|}{ C. lagenarium (CL2) } & 83.50 & 85.00 & 70.50 & 78.50 & 79.50 & 66.50 \\
\hline \multicolumn{2}{|c|}{ C. lagenarium (CL3) } & 74.25 & 79.00 & 61.50 & 66.50 & 68.50 & 58.50 \\
\hline \multicolumn{2}{|c|}{ C. lagenarium (CL4) } & 68.75 & 71.50 & 57.25 & 63.00 & 66.50 & 51.25 \\
\hline \multicolumn{2}{|c|}{ C. lagenarium (CL5) } & 59.00 & 69.50 & 51.25 & 55.75 & 63.50 & 45.25 \\
\hline \multirow{2}{*}{\multicolumn{2}{|c|}{ C.D $(p=0.05)$}} & Media (M) & \multicolumn{2}{|c|}{ Temperature (T) } & \multicolumn{2}{|c|}{ Isolates (I) } & ( X T X I) \\
\hline & & 0.457 & \multicolumn{2}{|c|}{0.560} & \multicolumn{2}{|c|}{0.722} & 1.769 \\
\hline \multicolumn{2}{|l|}{ SE(m) } & 0.163 & \multicolumn{2}{|c|}{0.199} & 0.25 & \multicolumn{2}{|c|}{0.630} \\
\hline
\end{tabular}

Table.5 Conidial size and colony colour of different isolates on different media (pH 6.5) at temperature $30^{\circ} \mathrm{C}$

\begin{tabular}{|l|c|c|c|}
\hline \multirow{2}{*}{ Isolates } & \multicolumn{2}{|c|}{ Conidia size $(\boldsymbol{\mu m})$} & \multirow{2}{*}{ Colony colour } \\
\cline { 2 - 4 } & Potato dextrose agar & Oat meal agar & White \\
\hline C. lagenarium (CL1) & $14-23 \times 4.3-5.6^{*}$ & $14-24 \times 4.4-5.4$ & White \\
& $(18.20 \times 5.2)^{* *}$ & $(16.62 \times 4.68)$ & Yellowish \\
\hline C. lagenarium (CL2) & $15-26 \times 4.4-5.9$ & $15-26 \times 4.8-5.7$ & Pinkish white \\
\hline C. lagenarium (CL4) & $(23.40 \times 5.65)$ & $(20.28 \times 5.21)$ & \\
\hline C. lagenarium (CL5) & $13-24 \times 4.2-5.6$ & $14-21 \times 4.5-5.3$ & Light Brownish \\
& $(21.52 \times 5.34)$ & $(18.20 \times 4.79)$ & \\
\hline
\end{tabular}

* Range of conidia size ** Average size of conidia 
Table.6 Sporulation of different isolates of $C$. lagenarium on different media (pH 6.5) at temperature $30^{\circ} \mathrm{C}$

\begin{tabular}{|l|c|c|}
\hline \multirow{2}{*}{ Isolates } & Media $\rightarrow$ & \multicolumn{2}{|c|}{ Sporulation $\left(\mathbf{1 0}^{\mathbf{4}}\right)$} \\
\hline & Potato dextrose agar & Oat meal agar \\
\hline C. lagenarium (CL1) & 59.07 & 43.83 \\
\hline C. lagenarium (CL2) & 74.86 & 58.36 \\
\hline C. lagenarium (CL3) & 62.16 & 47.16 \\
\hline C. lagenarium (CL4) & 57.71 & 46.75 \\
\hline C. lagenarium (CL5) & 41.53 & 29.79 \\
\hline
\end{tabular}

From the present investigation, it was concluded that cultural and morphological variation among different isolates of $C$. lagenarium selected from different locations revealed that isolates differ in their growth rate on different media, temperature and $\mathrm{pH}$. Karnal (CL2) isolate was recorded to having maximum mycelial growth, conidia size and sporulation on both the media, whereas these morphological characters were observed least in Yamuna nagar (CL5) isolate. PDA medium was the superior media for fungal growth at $30^{\circ} \mathrm{C}$ temperature with $6.5 \mathrm{pH}$.

\section{References}

Anonymous, (2016). www.Indiastat.com. Christopher, D.J., Raj, T.S. and Kumar, R.S.R. (2013). Morphological and molecular variability in Colletotrichum capsici causing anthracnose of chilli in Tamilnadu. Plant disease research 28(2): 121-127.

Davis, R.D., Boland, R.M. \& Howitt, C.J. (1992). Colony descriptions, conidium morphology, and the effect of temperature on colony growth of Colletotrichum gloeosporioides isolated from Stylosanthes spp. growing in several countries. Mycological Research 96: 128-134.

Deyol, A. (2010). Variability and management of Colletotrichum capsici (Syd.) Butler and Bisby, the incitant of fruit rot of chilli (Capsicum annum).
Thesis, Department of plant pathology, C.C.S., Haryana Agrcultural University, Hisar, India, $61 \mathrm{pp}$.

Du. M., Schardl, C.L. and Vaillancourt, L.J. (2005). Using mating type gene sequences for improved phytogenetic resolution of Colletotrichum species complexes. Mycologiea 97: 641-658.

Freeman, S., Minz, D., Jurkevitch, E., Mayman, M., and Shabi, E., (2000). Molecular analysis of Colletotrichum species from almond and other fruits. Phytopathology 90: 608-614.

Gardner, M.W., (1918). Anthracnose of cucurbits. United State Department of Agriculture Bulletin 727: 1-68.

Jeyalakashmi, C. and Seetharaman, K.L. (1999). Studies on the variability of isolates of Colletotrichum capsici (Syd.) Butler and Bisby causing chilli fruit rot. Crop Research 17: 94-99.

Kobayashi, Y., Kimishima, E. and Tokei, R. (1998). Anthracnose of pumpkin caused by Colletotrichum orbiculare (Berk. And Mnt.) Arx intercepted in important plant quarantine in Japan. Research Bulletin of the Plant Protection Service, Japan 34: 55-58.

Latunde-Dada, A.O. (2001). Colletotrichum: Tales of forcible entry, stealth, transient confinement and breakout. Molecular Plant Pathology 2: $187-$ 198.

Lenne, J.M., Sonoda, R.M. and Parbery, D.G. 
(1984). Production of conidia by setae of Colletotrichum species. Mycologia 76:359-362.

Madan, R.L. and Grover, R.K. (1977). Some pathological studies on anthracnose affecting bottlegourd. Indian Phytopathology 30 : 392-398.

Madan, R.L. and Grover, R.K. (1977). Some pathological studies on anthracnose affecting bottlegourd. Indian Phytopathology 30: 392-398.

Mundkur, B.B. (1937). Anthracnose of cucurbits in Punjab. Current Science 12: 647.

Palarpawar, M.Y. (1987). Growth and sporulation of Colletotrichum capsici and Colletotrichum curcumae on different culture media. Indian Journal of Mycology and Plant Pathology 17: 208.

Photita, W., Taylor, P.W.J., Ford, R., Lumyong, P., McKenzie, M.C. and Hyde, K.D. (2005). Morphological and molecular characterization of Colletotrichum species from herbaceous plants in Thailand. Fungal
Diversity 10: 117-133.

Than, P.P., Jeewon, R., Hyde, K.D., Pongsupasamit, S., Mongkolporn, O. and Taylor, P.W.J. (2008a). Characterization and Pathogenicity of Colletotrichum species associated with anthracnose on chilli (Capsicum spp.) in Thailand. Plant Pathology, 57: 562572.

Thaung, M.M. (2008). Coelomycete systematic with special reference to Colletotrichum. Mycoscience 49: 345350.

Vanan, T. (2001). Studies on the variability in Colletotrichum capsici (Syd.) Butler and Bisby, the incitant of fruit rot of chillies (Capsicum annum). M.Sc. (Plant Pathology) Thesis, Deptt. of Plant Pathology, CCS Haryana Agricultural University, Hisar, India. pp 69.

Zakaria, M. (2000). Morphology and cultural variation among colletotrichum isolates obtained from tropical forest nurseries. Journal of Tropical Forest Science 12(1): 1-20.

\section{How to cite this article:}

Ankit Kumar, Narender Singh, Kushal Raj, R.S. Chauhan and Manoj Kumar. 2019. Cultural and Morphologically Variability in Different Colletotrichum lagenarium Isolates of Bottle Gourd in Haryana. Int.J.Curr.Microbiol.App.Sci. 8(06): 420-427. doi: https://doi.org/10.20546/ijcmas.2019.806.047 